\title{
SMOOTH GOOSEFOOT REDISCOVERED IN MANITOBA
}

DIANA BIZECKI ROBSON, The Manitoba Museum, 190 Rupert Avenue, Winnipeg, MB R3B 0N2, E-mail: <drobson@manitobamuseum.ca>, JASON GREENALL, CARY HAMEL and CATHY FOSTER, Manitoba Conservation, Wildlife and Ecosystem Protection Branch, 200 Saulteaux Cres., Winnipeg, MB R3J 3W3. E-mail: $<$ jgreenall@gov.mb.ca>

\section{Introduction}

Smooth Goosefoot (Chenopodium subglabrum (S. Wats.) A. Nels.), is a nationally rare annual plant that typically grows in active to semi-stabilized sand dunes and blowouts, and along eroding, sandy river banks and coulees. ${ }^{2,5,8,10}$ B. Boivin and E. Laisley collected one specimen of Smooth Goosefoot in the Oak Lake Sand Hills of Manitoba in 1959. Despite periodic searches over several decades by botanists at the Manitoba Conservation Data Centre (MCDC), The Manitoba Museum and University of Manitoba, no other plants have been found. As 45 years had passed since this species was first found, the MCDC was considering changing the status of this plant from S1 (very rare throughout its range or in the province) to SH (historically known) or SX (believed to be extirpated provincially). ${ }^{6}$ The rediscovery of Smooth Goosefoot in Manitoba in the summer of 2004 ensures that it will retain its S1 status and possibly be legally protected under Manitoba's Endangered Species Act, 1990.

Manitoba has six major areas of sand hills in the southwestern corner of the province: Brandon, Lauder, Oak Lake, Routledge, Souris and St. Lazare. ${ }^{3}$ The Brandon Sand Hills (also known as Assiniboine Delta and Carberry Sand Hills) are the largest, covering $964 \mathrm{~km}^{2}$; part of this area lies within the borders of Spruce Woods Provincial Park. The Souris, Oak Lake, Lauder and Routledge Sand Hills west of Brandon, are adjacent to each other and together cover about $198 \mathrm{~km}^{2}$. The St. Lazare Sand Hills, covering only 62 $\mathrm{km}^{2}$, occur along the Assiniboine River near the Saskatchewan border.

Active sand dunes are dynamic habitats so their exact location changes over time. Elizabeth Punter (pers. comm.) noted that open sand dunes are shown about $6.4 \mathrm{~km}$ north of Oak Lake on the 1959 edition of the $62 \mathrm{~F} / 15$ 1:50 000 provincial topographic map. However, her impression of that area now is that it is "treed or scrub, grazed, or had houses built on it, and possibly may have been disturbed (for sand and gravel) when the highway was rebuilt." If this was the area where Smooth Goosefoot was first found, it is likely no longer suitable habitat, as this species requires some active sand. Only the Brandon Sand Hills contain actively moving sand dunes; the other sand hills in Manitoba contain some bare sand in the form of sand plains, semi-stabilized dune ridges and/or exposed blowouts. "

Unlike the sand hills in Alberta and Saskatchewan, Manitoba's sand hills contain significant cover of woody species such as alder (Alnus spp.), American Elm (Ulmus americana), Balsam Poplar (Populus balsamifera), birch (Betula spp.), Bur Oak (Quercus macrocarpa), Chokecherry (Prunus virginiana) and Manitoba Maple (Acer negundo). This is largely because Manitoba's sand hills occur in the moister and more fertile Aspen Parkland ecoregion 


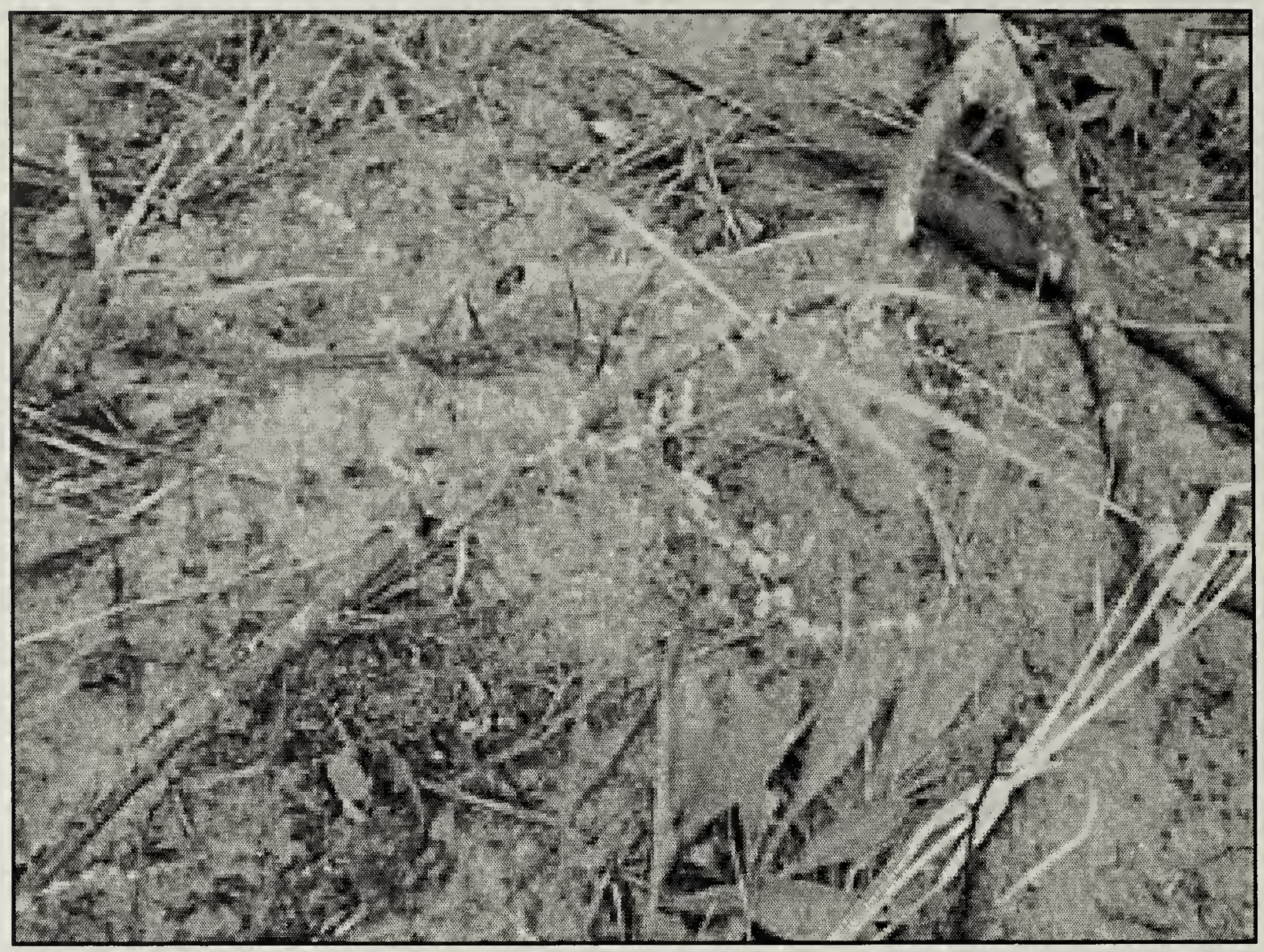

Figure 1. Smooth Goosefoot (centre) growing in the Routledge Sand Hills, August 23, 2004

Diana Robson

rather than the Moist Mixed Grassland and Mixed Grassland ecoregions where the major Alberta and Saskatchewan sand hills occur.

\section{Field Observations in 2004}

While conducting Smooth Goosefoot surveys we found this species in the Routledge Sand Hills of Manitoba on August 23, 2004 (Figure 1). Rather than visiting the Oak Lake Sand Hills where the first population was found, we decided to visit a nearby dune ridge in the Routledge Sand Hills that contained a population of the nationally rare Western Spiderwort (Tradescantia occidentalis). The bare sand at this site was thought to be appropriate habitat for Smooth Goosefoot.

At this site, Smooth Goosefoot plants were growing on an eroding dune ridge that had partly stabilized (Figure 2). Two plants were growing about $2 \mathrm{~m}$ apart on a westfacing slope, and a second group of 17 plants was spread over a $36 \mathrm{~m}^{2}$ area on a southfacing slope approximately $20 \mathrm{~m}$ away. All plants observed were in flower or in seed. The areas where the Smooth Goosefoot was growing had about $40 \%$ vegetation cover. Associated species included Narrowleaf Goosefoot (Chenopodium pratericola), Nuttall's Sunflower (Helianthus nuttallii), Hairy Golden Aster (Heterotheca villosa), Creeping Juniper (Juniperus horizontalis) and wild roses (Rosa spp.). Six provincially rare plants also occurred in the same area: Sand Bluestem (Andropogon hallii), Sand Nut-grass (Cyperus schweinitzii), Ball Cactus (Escobaria vivipara), Annual Skeletonweed (Lygodesmia rostrata), Louisiana Broom-rape (Orobanche ludoviciana) and Indian Rice Grass (Achnatherum hymenoides). ${ }^{6}$ The Louisiana Broom-rape had never been recorded on this dune ridge before. Voucher specimens and digital photographs of Smooth Goosefoot and Louisiana Broom-rape were taken and are filed at The Manitoba Museum. 


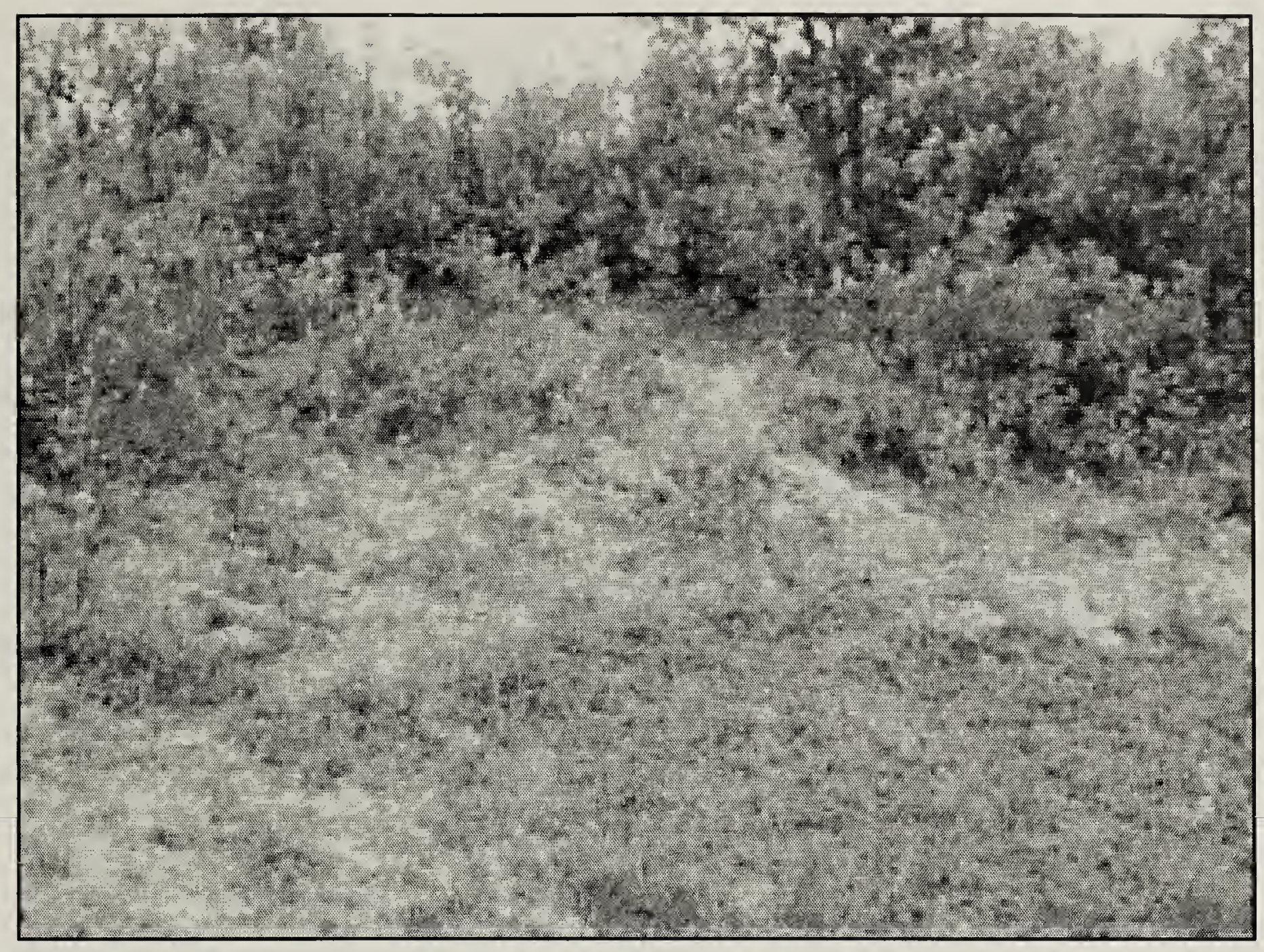

Figure 2. The partly stabilized dune ridge habitat of Smooth Goosefoot in the Routledge Sand Hills, August 23, 2004

Diana Robson

On August 25, 2004 Smooth Goosefoot was searched for in the Brandon Sand Hills along Spirit Sands Trail in Spruce Woods Provincial Park but only Narrowleaf Goosefoot was observed. Nonetheless, the species may still be present, since this area is large and not all of it was searched. None of the other sand hills in Manitoba was searched.

\section{Discussion}

There are several possible reasons why Smooth Goosefoot was not found growing at this site in previous years. One is that botanists visiting the sand hills did not see this inconspicuous plant. Smooth Goosefoot is often less than $10 \mathrm{~cm}$ tall and, if hidden amongst taller vegetation, would not be detected easily, especially if the population is small. Furthermore, Smooth Goosefoot closely resembles Narrowleaf Goosefoot, which occurs in the same habitat (Table 1). ${ }^{7}$ Since detecting most of the distinguishing characters requires close examination, anyone not inspecting each Chenopodium plant in the area could overlook Smooth Goosefoot.

The second possible reason for the lack of detection in the past relates to the annual nature of Smooth Goosefoot. Annual plants in dry environments, like sand hills, go dormant and germinate, grow and produce seeds rapidly when moisture is temporarily available. ${ }^{4}$ Lamont and Gerry asserted that dry weather could limit the persistence or spread of Smooth Goosefoot. ${ }^{5}$ The dramatic increase in the number of individuals observed by the first author at most sites in Saskatchewan in 2004, coupled with the observation that the summer of 2004 was unusually wet and cool, suggests that maximum seed germination occurs under moist conditions. This means that Smooth Goosefoot seeds are likely capable of remaining dormant for many years, possibly even decades, only germinating under appropriate conditions. If the sand hills were visited in dry years, or more specifically in 
Table 1. Key taxonomic differences between Smooth and Narrowleaf Goosefoot. ${ }^{7}$

\begin{tabular}{|c|c|c|}
\hline Character & Smooth Goosefoot & Narrowleaf Goosefoot \\
\hline No. leaf veins & One & Three \\
\hline Seed size & $\sim 1.5 \mathrm{~mm}$ & $0.9-1.2 \mathrm{~mm}$ \\
\hline Leaf vestiture & $\begin{array}{l}\text { Glabrous to very sparsely } \\
\text { farinose }\end{array}$ & Moderately to densely farinose \\
\hline Leaf shape & Linear & Linear to lanceolate or oblong-elliptic \\
\hline Leaf margin & Entire & Entire or toothed \\
\hline
\end{tabular}

years when rainfall did not occur in late summer, Smooth Goosefoot may have been present only in the seed bank.

\section{The Manitoba population of Smooth} Goosefoot is disjunct from the species' main range. The closest known population in Canada is about $550 \mathrm{~km}$ to the northwest in the Pelican Lake Sand Hills near Caron, Saskatchewan, and the closest known population in the United States is about 350 $\mathrm{km}$ to the southwest in the Little Missouri National Grassland of North Dakota. ${ }^{9}$ The Manitoba population may be unique genetically due to its isolation. Additional field work in other sand hills of Manitoba is required to determine the health and true extent of this rare, outlying population.

\section{Acknowledgements}

Funding for this research was provided by Environment Canada in connection with field work for a COSEWIC status report, and Manitoba Conservation. Thanks to Cindi Steffan for reviewing this paper.

1. ACTON, D.F., G.A. PADBURY, and C.T. STUSHNOFF. 1998. The Ecoregions of Saskatchewan. Canadian Plains Research Center, Univ. Regina, Regina.
2. ARGUS, G.W., and K.M. PRYER. 1990. Rare Vascular Plants in Canada. Canadian Museum of Nature, Ottawa.

3. DAVID, P.P. 1977. Sand dune occurrences of Canada. Parks Canada, Department of Indian and Northern Affairs, Ottawa.

4. GRIME, J.P. 1979. Plant Strategies and Vegetation Processes. John Wiley \& Sons, Bath, U.K.

5. LAMONT, S., and A. GERRY. 1998. Species status report Chenopodium subglabrum (S. Wats.) A. Nels. Saskatchewan Conservation Data Centre, Regina.

6. MANITOBA CONSERVATION DATA CENTRE. 2004. Vascular plant list. Web site: http:// web2.gov.mb.ca/conservation/cdc/. (Accessed November 2004).

7. MOSS, E. 1983. Flora of Alberta. University of Toronto Press, Toronto

8. ROBSON, D.B. 1997. Ecology of Rare Vascular Plants in Southwestern Saskatchewan. M.Sc. dissertation, Univ. Saskatchewan, Saskatoon.

9. SCHMOLLER, D. 2002. Chenopodium subglabrum surveys 2002 field season. Yellowfield Biological Surveys, North Dakota.

10. SMITH, B., and C. BRADLEY. 1990. Status report on the Smooth Goosefoot Chenopodium subglabrum (S. Wats.) A. Nels. Committee on the Status of Endangered Wildlife in Canada, Ottawa.

11. WOLFE, S.A. 2001. Eolian deposits in the Prairie Provinces of Canada. Natural Resources Canada, Ottawa.

\footnotetext{
"In the nineteenth century orchids were collected by the ton. Once, four thousand trees were cut down for the orchids growing on them. One collector alone was said to have sent one hundred thousand orchids to England, many of which died.

Wilhelm Micholitz sent home an orchid growing in a human skull, which was auctioned for a hugh sum complete with container."
} 